\title{
INTEGRASI SOSIAL DALAM MASYARAKAT MULTI ETNIK
}

\author{
Eka Hendry Ar., dkk. \\ STAIN Pontianak \\ e-mail: ekahendryar@yahoo.com
}

\begin{abstract}
This is a social research focused on the processes of society integration in the period of post-conflict. Locus of research is in Kelambu, a village in Sambas Regency West Kalimantan Province in which in 1999 a bloody violence broken between ethnic groups living there. Applying sociological approach and the perspective of conflict study, it was revealed that so far community living in Sungai Kelambu village is in negative peace because negative effect of the last confict is still there.

Penelitian ini merupakan penelitian ilmu sosial yang mempelajari tentang proses integrasi dalam masyarakat post konflik. Penelitian ini difokuskan di sebuah desa di Kabupaten Sambas Kalimantan Barat yang pada tahun 1999 diketahui pernah terjadi konflik sosial berdarah antarsuku. Dengan menggunakan pendekatan sosiologis dengan perspektif studi konflik ditemukan bahwa masyarakat saat ini dalam keadaan damai negatif karena ekses negatif dari konflik tersebut dirasakan sampai hari ini.
\end{abstract}

Keywords: integrasi, konflik sosial, post konflik, Sambas, damai, negatif 


\section{A. Pendahuluan}

Sebagai sebuah provinsi, Kalimantan Barat dibentuk dengan tingkat ragam budaya yang tinggi, baik dari segi keragaman suku, agama, dan adat istiadat. Keragaman tersebut semestinya menjadi modal dan kekuatan sosial bagi daerah ini. Idealitas tersebut seakan menjadi slogan semata manakala realitas konfliksuku berulang-ulang terjadi seperti di Kabupaten Sambas. Misalnya menurut catatan kepolisian daerah Kalbar (1999) bahwa, antara rabun 1963 hingga 1999 paling tidak telah terjadi kurang lebih 12 kali konflik okal antarsuku di Kalbar. ${ }^{1}$

Kini konflik kekerasan telah berakhir namun status konflik tersebut masih pada tarap simmering, yaitu belum terselesaikan akar konfliknya. Hal tersebut dibuktikan dengan tidak diperkenankannyasuku Madura kembali ke Sambas. Selain itu semakin berkembangnya embrio prasangka negatif.

Kalimantan Barat tepatnya di daerah Sambas pernah menorehkan sejarah penuh darah tepatnya tahun 1999, yaitu konflik suku Melayu (Sambas) dengan suku Madura. Menurut artikel yang dimuat dalam "Kontras" yang ditulis Munir (1999) sekitar 1800 tempat tinggal hancur. Banyak nyawa melayang dan kerugian materi atau infrastruktur (tanah, sawah, kebun dan hewan temak) yang diakibatkan dari tragedi tersebut tidak terhitung. Maka tidak mengherankan Sambas di mata pemerintahan pusat (Jakarta) dikategorikan sebagai "kawasan merah" yang perlu mendapatkan prioritas khusus dalam hal penanganan konflik.

Kata "harmonisasi dan rekonsiliasi" seakan hanya bagi tiga suku besar: Dayak, Melayu dan Cina. Bagi suku Madura yang ada hanya kata zero tolerance (tidak ada toleransi) karena tidak ada dapat memberikan jaminan keselamatan bagi masyarakat Madura yang ingin kembali ke Sambas sebagai tempat kelahiran mereka. Bahkan dari pemerintah tampak tidak berdaya, meskipun Pemerintah Daerah telah menetapkan Peraturan Daerah (Perda) Provinsi Kalbar No. 10/2005 tentang membangun harmonisasi antarsuku di

1 Munawar, Sejarah Konflik Antarsuku di Kabupaten Sambas, (Pontianak, Kalimantan Persada dan The Ford Foundation, 2003), h. 3-4. Marzali, (2003), "Perbedaan Suku dalam Korflik: Sebuah Analisis Sosio Ekonomi Terhadap Kekerasan di Kalimantan”, dalam Stokhof. W.A.L dan Djamal, mumi (redaktur) 2003, Konflik Komunal di Indonesia Saat ini, Oakarta, Indonesia-Netherlands Cooperation en Islamic Studies [INIS], 2003), h. 5. Eka Hendry, dkk, Prasangka Antar Kelompok Suku di Kalimantan Barat, (Pontianak: STAIN Pontianak Press, 2003), h. 201. 
Kalbar masuk dalam RPJMD Provinsi Kalbar 2006-2008. Perda tersebut menetapkan visi pembangunan daerah, yaitu terwujudnya masyarakat Kalbar yang harmonis dalam suku, maju dan tertib dalam pemerintahan. ${ }^{2}$

Sei Kelambu (selanjutnya dibaca: sungai) dalam konteks ini masih menyimpan benih integrasi sosial. Berbeda daerah Sambas lainnya, di Desa Sei Kelambu Kecamatan Tebas seakan teralienasi dari pengaruh konflik kekerasan Sambas. Di Sei Kelambu, berapa keluarga Madura masih dapat bertahan di sana, bahkan menjadi tokoj masyarakat. Padahal ketika terjadi kerusuhan massal pada tahun 1999 di pusat Kota Tebas, yang hanya beberapa kilometer dari Sei Kelambu merupakan pusat pertikaian berdarah. Jika kawasan kerusuhan itu dibagi menjadi tiga zona; zona merah untuk pusat kerusuhan, zona kuning untuk kawasan yang terimbas kerusahan dan zona hijau daerah yang bebas, maka Tebas bisa dikategorikan sebagai zona merah. Suasana kerusuhan itu masih terasa hingga beberapa tahun kemudian. Pasca kerusuhan massal itu, beberapa orang Madura mencoba kembali melihat kampung halamannya di kabupaten Sambas namun sebelum sempat sampai ke kampung asalnya yang bersangkutan sudah dibunuh.

Integrasi sosial seperti yang ditemukan di Sei Kelambu diharapkan menjadi trigger bagi daerah-daerah lain, yang tidak hanya terbatas pada "kawasan merah" Sambas. Dengan kata lain kelak akan menjadi embrio bagi penguatan potensi integrasi sosial di Kalimantan Barat. Karena dalam kenyataannya masih ada orang Madura yang bisa tinggal di kampung yang disekitamya merupakan pusat pertikaian berdarah. Sedangkan banyak kampung di kawasan sekitamya tidak ada lagi orang Madura.

\section{B. Integrasi dan Disintegrasi Sosial}

Kamus Besar Bahasa Indonesia mengartikan "integrasi" sebagai pembauran hingga menjadi kesatuan. ${ }^{3}$ Kata "kesatuan" mengisyaratkan berbagai macam elemen yang berbeda satu sama lain mengalami proses pembauran. Jika pembaruan telah mencapai suatu perhimpunan, maka gejala perubahan ini dinamai integrasi. Dalam bahasa Inggris, integrasi (integration) antara lain bermakna "keseluruhan" atau "kesempurnaan."

\footnotetext{
2 Pontianak Post, 31 Mei 2008.

${ }^{3}$ Depdikbud, Kamus Besar Bahasa Indonesia, (Jakarta: Balai Pustaka, 1998).
} 
Jika berbagai macam elemen yang berbeda satu sama lain merujuk pada kemajemukan sosial yang telah pula mencapai suatu kehidupan bermasyarakat, maka proses ini dinamai integrasi sosial. Dalam sosiologi, integrasi sosial berarti proses penyesuaian unsur-unsur yang saling berbeda dalam kehidupan masyarakat sehingga menghasilkan pola kehidupan masyarakat yang memiliki keserasian fungsi. Dengan demikian, ada dua unsur pokok integrasi sosial. Unsur pertama adalah pembauran atau penyesuaian, sedangkan unsur kedua adalah unsur fungsional. Jika kemajemukan sosial gagal mencapai pembauran atau penyesuaian satu sama lain, maka kemajemukan sosial berarti disentegrasi sosial. Dengan kata lain, kemajemukan gagal membentuk (disfungsional) masyarakat.

Integrasi sosial memang persoalan menarik dan penting secara akademik. Sekurang-kurangnya, teori-teori sosial mengenai integrasi, accelerator faktor integrasi sosial, dan disentegrasi sosial dapat digolongkan ke dalam dua teori induk, yaitu teori struktural dan teori kultural. Setelah menjelaskan pokok-pokok teori struktural dan kultural, pembicaraan akan dilanjutkan dengan menyoroti hasil terapan teori-teori tersebut dalam menjelaskan tipologi masyarakat di negara berkembang, entah masyarakat pedesaan maupun pekotaan.

Studi-studi sosial di Indonesia umumnya mengenal pembedaan masyarakat dalam dua tipologi tegas, yaitu masyarakat pedesaan dan perkotaan. Desa dibayangkan dan diperkenalkan sebagai wilayah sosial dengan karakteristik khas masyarakatnya, seperti mengutamakan harmonisasi ketimbang konflik, mematuhi nilai tradisional, memiliki semangat kolektivitas, kekeluargaan, dan berbagai karakteristik sopan-santun atau ramah-tamah lainnya. Kota digambarkan sebagai wilayah yang dihuni oleh masyarakat berkarakteristik individualis, egois, kompetitif, produktif, dan berbagai karakteristik manusia modem lainnya.

Desa adalah sebuah pengertian sosial atau konsep yang merujuk pada orang-orang atau sekumpulan individu yang saling berhubungan antara satu sama lain yang tinggal di suatu tempat di luar daerah perkotaan. Hubungan sosial masyarakat pedesaan biasanya didasarkan pada kekuatan ikatan tali persaudaraan, kekeluargaan dan ikatan perasaan secara psikologis. Hubungan-hubungan sosial pedesaan mencerminkan kesatuan-kesatuan kelompok yang didasari hubungan kekerabatan atau garis keturunan. 
Terkadang desa dihuni oleh beberapa kelompok kerabat atau keturunan, terkadang pula hanya dihuni oleh warga dari garis keturunan yang sama.

Latar belakang perpaduan beberapa orang atau kelompok suku atau keturunan di pedesaan ialah karena didorong oleh upaya untuk memenuhi kebutuhan yang sama dari sekumpulan individu, dan perasaan senasib bahwa mereka dapat memenuhi hajat kehidupan masing-masing. Situasi ini oleh Cooley disebut community atau masyarakat setempat (selanjutnya disebut komunitas). Menurut Cooley, identitas sosial komunitas adalah (1) anggota-anggota kelompok secara fisik berdekatan satu sama lain; (2) jumlah anggotanya kecil; (3) kelanggengan hubungan antar anggota-anggota kelompok; dan (4) keakraban relasi sosial. ${ }^{4}$

Keakraban relasi sosial antar anggota kelompok bergantung pada intensitas kontak langsung antar anggota. Keakraban relasi sosial berjalan seiring dengan proses homogenasi cita-cita kelompok, dan berpengaruh langsung terhadap kelanggengan kehidupan bersama. Jika keakraban relasi sosial telah terjalin sedemikian lama, maka menciptakan keakraban sosial itu sendiri menjadi tujuan masyarakat pedesaan.

Dengan demikian jelas bahwa hubungan-hubungan antara individuindividu sebagai anggota kelompok tidak semata hanya didasarkan atas perjanjian, peraturan-peraturan yang ada dan pola perilaku yang berhasil diciptakan yang telah disepakati bersama. Akan tetapi yang paling penting bagi kelanggengan bagi hubungan itu adalah terletak pada tinggi atau rendahnya rasa kesetiaan dan pengabdian dari setiap anggota terhadap kesatuan kelompok yang diselenggarakan menurut pola perilaku dan norma yang telah diakui bersama.

Kelangsungan kehidupan masyarakat pedesaan sangat dipengaruhi oleh kekuatan ikatan sosial, larangan dan kewajiban yang digariskan sebagai adat istiadat. Derajat ikatan sosial dapat diukur dengan seberapa kuat nilai-nilai solidaritas dan sentimen masyarakat. Jika solidaritas dan sentimen diakui secara terbatas, lokalitas (daerah asal), maka kehidupan masyarakat disebut community sentiment. Oleh Mac Iver dan Charles H. Page, unsur-unsur community sentiment antara lain adalah: 5

${ }^{4}$ Soerjono Soekanto, Sosiologi Suatu Pengantar, (Jakarta: Raja Grafmdo Persada, 1982), h. 138

5 Ibid., h. 164. 
1. Seperasaan: Unsur seperasaan akibat bahwa seseorang berusaha untuk mengidentifikasikan dirinya dengan sebanyak mungkin orang dalam kelompok tersebut, sehingga kesemuanya dapat menyebutkan dirinya sebagai "kelompok kami”, "perasaan kami” dan lain sebagainya. Perasaan demikian terutama timbul apabila orang-orang tersebut mempunyai kepentingan-kepentingan yang sama di dalam memenuhi kebutuhankebutuhan hidupnya. Unsur seperasaan tersebut harus memenuhi kebutuhan-kebutuhan kehidupan dengan "altruism", yang lebih menekankan pada perasaan solider dengan orang lain. Pada unsur seperasaan, kepentingan-kepentingan si individu diselaraskannya dengan kepentingan kepentingan kelompoknya, sehingga dia merasakan kelompoknya sebagai struktur sosial masyarakatnya.

2. Sepenanggungan: Setiap individu sadar akan perannya dalam kelompok dan keadaan masyarakat sendiri memungkinkan bahwa perannya dalam kelompok dan keadaan masyarakat sendiri memungkinkan bahwa peranannya tadi dijalankan, sehingga dia mempunyai kedudukan yang pasti dalam darah dagingnya sendiri.

3. Saling memerlukan: Individu yang tergabung dalam masyarakat setempat merasakan dirinya tergantung pada "community"nya yang meliputi kebutuhan fisik maupun kebutuhan-kebutuhan psikologisnya. Kelompok yang tergabung dalam masyarakat setempat tadi, memenuhi kebutuhan-kebutuhan fisik seseorang, misalnya atas makanan dan perumahan. Secara psikologis, individu akan mencari perlindungan pada kelompoknya apabila dia berada dalam ketakutan, dan lain sebagainya.

Kesadaran sosial komunitas pedesaan terwujud pada kebiasaan, tradisi, perilaku tertentu dan bahasa yang khas. Dalam Sosiologi Kelompok dan Masalah Sosial, Abdulsyani (1984) menandaskan tingkat-tingkat kesadaran kelompok sebagai berikut:

1. Tingkat kesadaran akan tujuan-tujuan kelompok yang telah disepakati bersama. Untuk itu berarti kesadaran bisa ditingkatkan melalui usaha menanamkan keyakinan terhadap anggota-anggota kelompok, bahwa suatu tujuan yang ingin dicapai adalah merupakan tujuan dari seluruh anggota kelompok juga.

2. Tingkat kesadaran suatu kelompok terhadap seluruh anggotanya, artinya menanamkan rasa tanggung jawah kelompok terhadap seluruh anggotanya, seperti jaminan hidup, jaminan keamanan, dan sebagainya. 
Dengan demikian diharapkan dapat pula menimbulkan rasa tanggung jawab anggota-anggotanya terhadap kelompoknya.

3. Tingkat perasaan saling ketergantungan antara sesama anggota kelompok, artinya jika antara sesama anggota kelompok itu mempunyai rasa saling membutuhkan dalam usaha pencapaian tujuannya, maka hal itu suatu pertanda bahwa persatuan kelompok tersebut relatif lebih langgeng keberadaanya.

4. Tingkat aktivitas interaksi antara anggota-anggota kelompok, artinya jika aktivitas interaksi antara sesama anggota kelompok itu Iemah, maka akan semakin sedikit pula manfaatnya bagi usaha pencapaian tujuantujuan dari kelompok yang bersangkutan.

Nilai solidaritas dan sentimen masyarakat pedesaan dianggap dapat memberikan kehidupan tenteram dan damai. Inilah sebabnya mengapa kepercayaan terhadap tokoh sakti dan cerita tradisional begitu mudah diterima oleh masyarakat pedesaan. Dengan kata lain, bentuk dan corak kehidupan masa lampau menjadi bagian kesadaran sosial masyarakat pedesaan.

Menurut Koentjaraningrat ${ }^{6}$ bagi masyarakat pedesaan, nilai solidaritas merupakan kebutuhan umum yang dinilai lebih tinggi daripada kebutuhan individu. Koentjacaraningrat juga menyebutkan bahwa solidaritas terwujud dalam bentuk bekerja bakti untuk umum, gotong royong, yang dianggap suatu hal yang sangat terpuji dalam sistem hukum pedesaan. Demikian pula bahwa hak-hak individu tidak secara jelas dan tajam untuk diutamakan. Ciriciri kehidupan masyarakat pedesaan yang demikian inilah oleh Ferdinand Tonnies disebut Gemeinschaft.7

Tonnies kemudian melangkah atau "meramal" lebih jauh. Bagi dia, Gemeinschaft lambat laun akan bergeser ke bentuk lain yang mencerminkan nilai-nilai kelembagaan sosial yang lebih teratur dan terkoordinasi. Hubungan-hubungan sosial akan diatur oleh wadah khusus atau, lebih tepatnya, organisasi sosial. Dalam keadaan normal, mula-mula perkembangan ini tidak menganggu stabilitas kehidupan masyarakat, apalagi perkembangan tersebut tidak meninggalkan nilai kepuasan batin dan sosial.

\footnotetext{
${ }^{6}$ Koentjaraningrat, Beberapa Pokok Antropologi Sosial, (Jakarta: Dian Rakyat, 1967).

${ }^{7}$ Ferdinand Tonnies and Charles P. Loomis, "Gemeinschaft and Gesellschaft" dalam Reading in Sociology, editor Mc. Clung Lee, (Bamers dan College Outlines Series, 1960).
} 
Namun demikian, sebagaimana ditenggarai oleh Koentjaraningrat, 8 organisasi-organisasi baru yang komplek itu turut memandulkan kepekaan jiwa tolong menolong masyarakat pedesaan, dan lambat laun namun pasti mendorong kemunculan jiwa individualis.

Pada masyarakat yang individualistik, kebutuhan umum dikalahkan oleh kebutuhan individu. Kerja bakti dianggap tak banyak berguna. Hak-hak individu dipertahankan secara tegas dan tajam, sedangkan hasil kerja individu bemilai tinggi. Perhitungan yang berlaku adalah perhitungan ekonomis. Kepuasan batin dan sosial bertukar pasang dengan kepuasan ekonomis dan politik. Kehidupan demikian, oleh Tonnies, disebut Gesellschaft atau boleh dinamai masyarakat pekotaan.

Dengan demikian, peralihan dari Gemeinschaft ke Gesellschaft adalah peralihan yang menyimpan risiko alineasi sosial kalau bentuk masyarakat baru itu dipersepsi sebagai ancaman terhadap stabilitas masyarakat lama. Inilah sebabnya orang desa umumnya menganggap bentuk kehidupan Gemeinschaft lebih baik ketimbang Gesellschaft. Sebaliknya orang kota menganggap Gesellschaft adalah bentuk masyarakat yang paling cocok. Sebabnya, Gesellschaft dibayangkan bakal lebih mampu menjamin kesejahteraan individu.

Sementara itu kehidupan kelompok pada masyarakat perkotaan lebih didasarkan atas kemauan yang diatur oleh cara berpikir yang rasional, dan segala sesuatunya dinilai atas dasar untung dan rugi. Mengenai hubungan antara orang perorangan dalam suatu kelompok dianggap sebagai alat untuk mencapai tujuan-tujuannya. Sebaliknya dalam kehidupan kelompok pada masyarakat pedesaan biasanya didasarkan atas ikatan hubungan batin dan perasaan yang tumbuh secara alami. Segala sesuatunya dinilai atas dasar rasa cinta dan kepuasan batin. Hal ini berarti tujuan hidup baru dapat dicapai apabila orang perorangan sebagai anggota kelompok dan masyarakat telah mendapatkan kepuasan batin. Sedangkan harta kekayaan bukanlah suatu ukuran yang dapat menjamin bagi seseorang untuk dapat hidup senang, puas dan bahagia.

\footnotetext{
${ }^{8}$ Koentjaraningrat, Beberapa Pokok Antropologi Sosial.
} 


\section{Demografi, Institusi Politik dan Ekonomi}

Jika dibandingkan dengan tahun sebelumnya, jumlah penduduk Desa Sungai Kelambu terbilang mengalami peningkatan signifikan. Data terakhir ${ }^{9}$ menunjukan total jumlah penduduk Desa Sungai Kelambu sebesar 3.154 jiwa. (laki-laki 1.568, perempuan 1.586) dengan 689 Kepala Keluarga (KK). ${ }^{10}$ Menjadi petani jeruk dan padi adalah mata pencaharian terbesar bagi penduduk (997 jiwa/31.61\%). Sebanyak 150 jiwa berkerja sebagai buruh tani, dan sebanyak 85 jiwa menjadi buruh swasta, entah bekerja sebagai Tenaga Kerja Indonesia (TKI) di Malaysia atau pekerja kayu di luar kabupaten atau luar daerah Kalimantan Barat, seperti Riau dan lain-lain. Sebanyak 65 orang menjadi Pegawai Negeri Sipil (PNS). Ada juga ada yang menjadi pengrajin kayu (lemari, kursi, tempat tidur, dan sejenisnya). Sebagian kecil lain bekerja sebagai nelayan (15 jiwa), pedagang (20 jiwa) petemak (15 jiwa) dan montir (4 jiwa).

Biokrasi modern meagadministrasi Desa Sungai Kelambu menjadi 2 (dua) Dusun Parit dan Dusun Sungai.

Tabel 1.

Komposisi Penduduk Dusun Parit Desa Sungai Kelambu

\begin{tabular}{cccc}
\hline $\begin{array}{c}\text { Rukun } \\
\text { Tetangga }\end{array}$ & \multicolumn{2}{c}{ Jenis Kelamin } & $\begin{array}{c}\text { Jumlah Kepala } \\
\text { Keluarga }\end{array}$ \\
\hline I & Laki & Perempuan & 48 \\
II & 101 & 103 & 54 \\
III & 102 & 104 & 57 \\
IV & 113 & 108 & 52 \\
V & 102 & 94 & 52 \\
VI & 113 & 113 & 58 \\
VII & 114 & 120 & 42 \\
\hline
\end{tabular}

Sumber: Data Kependudukan Kepala Dusun Parit, wawancara dengan

Hermanto Kepala Dusun Parit tang gal 28 Juli 2010

\footnotetext{
${ }_{9}^{9}$ Kecuali disebutkan StIfiiber lain, data diperoleh dari Da/tar lsiar: Potensi Desa Tahun 2009.

10 Pada 2007, total jumlah penduduk Desa Sungai Kelambu sebesar 2.867 (laki-laki 1.443, perempuan 1.424). Data Pemeriniahan dan Kependudukan Kecamatan Tebas Tahun 2007.
} 
Mayoritas penduduk Desa Sungai Kelambu pernah mengenyam pendidikan formal, bahkan beberapa orang berhasil mencapai jenjang pendidikan strata dua (magister)

Tabel 2.

Potensi Sumber Daya Manusia Bidang Pendidikan

\begin{tabular}{clc}
\hline No. & \multicolumn{1}{c}{ Sumber Daya Pendidikan } & Jiwa \\
\hline 1 & Belum mengenyam sekolah formal & 421 \\
2 & Tidak pernah mengenyam sekolah formal & 11 \\
3 & Pernah mengenyam Sekolah Dasar (SD) & 476 \\
4 & Tamat Sekolah Dasar (SD)/sederajat & 512 \\
5 & Tamat Sekolah Lanjutan Tingkat Pertama & 435 \\
& (SLTP)/sederajat & \\
6 & Tamat Sekolah Lanjutan Tingkat Atas & 396 \\
7 & (SLTA)/sederajat & 10 \\
8 & Diploma 1 & 37 \\
9 & Diploma 2 & 24 \\
10 & Diploma 3 & 28 \\
11 & Sarjana & 3 \\
\hline
\end{tabular}

Sumber: Daftar Isian Potensi Desa Sungai Kelambu, Kecamatan Tebas Tahun 2009

Meskipun Islam merupakan agama mayoritas di Desa Sungai Kelambu (99\% atau 3.135 jiwa), namun kemajemukan agama tak bisa dihindari. Segelintir penduduk memeluk agama Katolik (9 jiwa) dan Budha (10 jiwa). Nuansa dan pendidikan keislaman cukup kentara. Sebuah pondok pesantren Tahfiz Qur'an (menghafal al-Qur'an) telah berdiri dan akan dikembangkan lebih lanjut di desa ini. ${ }^{11}$

11 Diketuai oleh H. Mulyadi Haeruddin, satu-satunya hafidz (penghafal Qur'an) di Desa Sungai Kelambu, Bekerja sebagai Pegawai Negeri Sipil (PNS) pada Dinas Pendidikan Tebas. Pesantren tersebut telah berdiri dan berjalan selama 3 tahun. Walaupun untuk sementara pesantem tersebut hanya difungsikan sebagai lembaga pendidikan non-formal dan diperuntukkan untuk putera-puteri penduduk setempat saja, namun untuk ke depannya, Ponpes tersebut akan dikembangkan seperti Ponpes pada umumnya. Menurut kepala desa Sungai Kelambu, Deni Abdul Hadi, (30 tahun) telah banyak permintaan dari warga di luar desa Sungai Kelambu untuk menitipkan anaknya di Ponpes ini. Akan tetapi, untuk sekarang, keinginan tersebut belum bisa diwujudkan karena, selain tenaga pengasuh atau pengajar masih minim, asrama santri belum tersedia. (Wawancara tanggal 3 April 2010). 
Selain itu, penduduk Desa Sungai Kelambu mengenal multipartai politik. Partai politik yang paling menonjol ialah Partai Demokrat, Partai Demokrasi Indonesia Perjuangan (PDIP), Partai Golongan Karya (Golkar), Partai Persatuan Pembangunan (PPP), Partai Keadilan Sejahtera (PKS), Partai Hati Nurani Rakyat (Hannra), Partai Kebangkitan Bangsa (PKB), dan Partai Gerakan Indonesia Raya (Gerindra). Setiap partai politik tersebut memiliki kepengurusan setingkat desa atau, sering disebut, komisariat desa.

Meskipun terdapat Sungai Kelambu, dan sedemikian dekat dengan perairan sungai yang strategis itu, namun mayoritas masyarakat Desa Sungai Kelambu lebih memilih bekerja di daratan. Mayoritas masyarakat bercocok tanam, bukan terutama menanam padi dan jeruk. Kalau padi dan jeruk tak lagi menjanjikan, maka profesi altematif yang lebih menarik perhatian dan menjadi pilihan mereka adalah menjadi buruh; tenaga kerja di luar negeri, seperti Malaysia Brunei Darussalam. Seolah-olah mereka tak lagi melihat bahwa sumber daya perairan di sekitar mereka, Sungai Kelambu, menjanjikan kehidupan. Padahal, tanaman padi dan jeruk juga tak Iepas dari risiko. ${ }^{12}$

\section{Etnisitas}

Desa Sungai Kelambu merupakan desa multietnis. Kendati sebagian besar warga Sungai Kelambu adalah Melayu Sambas (2.995 orang), namun

\footnotetext{
${ }^{12}$ Sebagai sumber mata pencarian utama selain tanaman jeruk, tanaman padi tak lepas dari berbagai persoalan hama penyakit. Serangan Wereng. Tak banyak tindakan yang dapat dilakukan masyarakat petani di Desa Sungai Kelambu lantaran minimnya wawasan mereka tentang hama penyakit, Pemerintah melalui Dinas Pertanian dan Panitia Penyuluh Lapangan (PPL) setempat mendapatkan laporan atas serangan tersebut. Sehingga penyemprotan pestisida secara gratis diberikan kepada masyarakat yang memiliki lahan endemik hama. Namun, persoalan lain kembali muncul. Penyemprotan hama penyakit hanya dilakukan dengan melokalisir daerah endemik dengan jarak $150 \mathrm{~m} 2$. Padahal sebaran hama penyakit tidak hanya menumpuk pada satu lahan pertanian. Dengan demikian, penanganan melalui penyemprotan yang dilakukan Dinas Pertanian dirasakan masyarakat desa Sungai Kelambu masih belum optimal. Lain tanaman, lain pula hama penyakitnya. Tanaman jeruk merupakan komoditas unggulan di seluruh kawasan Sambas, tanpa terkecuali Desa Sungai Kelambu, Hama yang menyerang tanaman jeruk lebih dikenal dengan virus PTVD, masyarakat lebih menyakini bahwa penyakit tanaman jeruk ini dibawa oleh hama kutu loncat. Melalui Dinas Pertanian tindakan preventif yakni dengan mengamputasi bagian batang yang terifeksi penyakit, pihak Dinas beranggapan. serangan bama ini masih dalam kategori lambat, diperkirakan penyebaran hama $2 \mathrm{~cm} / 1$ bulan pada satu batang tanaman jeruk. Banyak penduduk melihat bahwa perkembangan serangan hama penyakit tanaman jeruk lebih cepat dari prakiraan dinas Pertanian. Mereka menyaksikan serangan hama dalam 1 minggu mampu membuat satu tanaman jeruk kering dan mati.
} 
suku Jawa (18 jiwa), Bugis (18 jiwa), Tiong Hoa (21 jiwa), Dayak (5 jiwa), dan Aceh (1 jiwa) juga menetap hidup di desa ini. Bahkan, suku Madura terhitung suku mayoritas kedua (58 orang) setelah Melayu Sambas, Padahal, suku tersebut terakhir ini pernah terusir dari wilayah Kabupaten Sambas akibat konflik atau kerusuhan sosial yang disertai tindak kekerasan fisik yang menelan kerugian harta dan nyawa.

Pada tahun 1999, konflik antarsuku Melayu Sambas dan Madura telah mengakibatkansuku Madura harus mengungsi dari atau diungsikan ke luar wilayah Kabupaten Sambas. Akan tetapi, konflik kekerasan antarsuku yang menerabas ke pelosok-pelosok desa di seluruh Kabupaten Sambas itu tidak mengubah secara radikal kehidupan multietnis, khususnya hubungan suku Melayu Sambas dan Madura di Desa Sungai Kelambu. Pada saat konflik kekerasan antarsuku memuncak, tidak ada suku Madura di Desa Sungai Kelambu yang menjadi korban. ${ }^{13} \mathrm{Hal}$ ini dimungkinkan oleh dua hal. Pertama, menyarankan suku Madura untuk mengungsi dari Desa Sungai Kelambu. ${ }^{14}$ Kedua, mencegah dan menghalang-halangi massa yang bermaksud menyerang suku Madura di Desa Sungai Kelambu, dengan cara melakukan sweeping senjata. ${ }^{15}$

Setelah konflik antarsuku di Kabupaten Sambas berhenti, suku Madura tetap tinggal di Desa Sungai Kelambu, Hal ini dimungkinkan oleh sejumlah faktor, entah karena "rate-rate urang Mendure ye kawin dengan urang Melayu"

${ }^{13}$ Berdasarkan cerita yang dipaparkan bapak Abdul Hadi, pada saat kerusuhan terjadi, tidak ada korban jiwa warga Madura dari Sungai Kelambu, Hal tersebut terjadi karena sebelum perang pecah, tokoh masyarakat berinisiatif mengungsikan terlebih dahulu semua warga Madura di sana. Waktu itu mereka diangkut dengan menggunakan truk, dan langsung dibawa ke Singkawang dengan dikawal polisi.

${ }_{14}$ Menurut Abdul Hadi, salah satu tokoh yang dituakan di desa Sungai Kelambu, mantan kepala desa, dan bapak kandung kepala desa sekarang, pada saat perang berkecamuk seorang Madura bemama Siman Mahad ngotot tidak mau mengungsi, meskipun ia telah disarankan oleh sebagian besar warga. Pak Siman Mahad bersikukuh dengan pendiriannya, tidak akan pergi dari desa Sungai Kelambu, meskipun ia harus mati di sana. Karena keteguhan pendiriannya tersebut, .akhimya warga menyerah dan tidak lagi berupaya memaksa beliau untuk ikut mengungsi dengan warga Madura lainnya. Ia dibiarkan tetap tinggal di Sungai Kelambu. Sayangnya, Pak Siman Mahad tidak mungkin lagi dihubungi, karena beliau sudah meninggal dunia seiak empat tahun silam

${ }^{15}$ Karena Sungai Kelambu merupakan jalan umum yang dijadikan pusat berkumpulnya penduduk dari desa-desa lainnya, maka Sungai Kelambu pada waktu itu juga terkesan tidak aman. Pada waktu kerusuhan meledak, mobil-mobil yang sarat dengan warga Melayu dan Dayak yang siap dengan senjata tajam dan senjata api selalu berkumpul terlebih dahulu di Sungai Kelambu. Mereka berkumpul guna mengatur strategi untuk menyerang warga Madura. Akan tetapi, beberapa kali tokoh masyarakat setempat berhasil mencegah mereka dengan cara melakukan sweeping senjata. 
(kebanyakan orang Madura telah menikah dengan orang Melayu),16 atau "udah macam nak urang Melayu juak (telah dianggap sebagai orang Melayu)", maupun karena "barang jak be darahnye dah becampur dan hidup dangan urang Melayu" (bukankah darahnya sudah bercampur dan hidup .di kalangan orang Melayu)."17 Meskipun masih dianggap berdarah atau keturunan Madura, namun penduduk Desa Sungai Kelambu tidak menyoal kedarahan atau keturunan demikian, Sebalikiiya, mereka menjamin keselamatan suku Madura.

Selama lima tahun terakhir, jika terjadi konflik antarsuku di desa Sungai Kelambu, maka penyelesaian dapat dilakukan secara kekeluargaan.18 Penyelesaian konflik bersifat internal dengan melibatkan tokoh masyarakat dan aparatur desa. Jika tidak bisa terselesaikan, barulah mereka menempuh jalur hukum.

Tabel 3.

Sebaran Suku Desa Sungai Kelambu

\begin{tabular}{clc}
\hline No. & \multicolumn{1}{c}{ Nama Suku } & Prosentase Sebaran \\
\hline 1 & Melayu & $94 \%$ \\
2 & Cina & $1 \%$ \\
3 & Madura & $1 \%$ \\
4 & Dayak & $2 \%$ \\
5 & Lain-lain & $2 \%$ \\
\hline
\end{tabular}

Sumber: Mustafa Munzir, wawancara tanggal 4 April 2010

Hingga saat ini, menurut Anwar, ${ }^{19}$ intensitas gotong royong antarsuku di Sungai Kelambu, seperti Melayu, Cina, dan Madura, masih mewarnai tradisi kehidupan desa. Gotong royong antarsuku mengental di berbagai kegiatan masyarakat desa, seperti panggelan (selamatan), perkawinan, dan peringatan hari raya keagamaan.

${ }^{16}$ Abdul Hadi, Wawancara tanggal 3 April 2010.

${ }^{17}$ Abdul Hadi, Wawancara tanggal 3 April 2010.

${ }^{18}$ Namun jauh sebelumnya pernah terjadi perkelahian antar pemuda yang dipicu oleh minuman keras (miras) yang berujung pada korban luka. Namun, konflik ini akhirnya bisa diselesaikan secara kekeluargaan, yakni dengan jalan memanggil kedua pihak yang bertikai dan diminta membuat perjanjian damai. Kasus selesai tanpa melibatkan pihak kepolisian.

${ }^{19}$ Selain dipandang sebagai tetua Desa Sungai Kelambu, pensiunan Kecamatan Tebas dan sekarang menjabat sebagai Wakil Ketua Lembaga Persataan Melayu (LPM) ini biasa dipanggil Long Anwar. (Wawancara tangga14 April 2010). 
Di Sungai Kelambu, penyelenggaraan pesta perkawinan senantiasa diawali dengan meteng. Dalam meteng, pihak yang bermaksud melaksanakan hajat perkawinan mengundang seorang tokoh masyarakat, entah Kepala Desa maupun Tetua Desa, untuk membicarakan prosesi perkawinan, seperti saprahan (pola penyajian jamuan bagi tetamu), hingga tarup (pentas utama untuk mempromosikan pengantin dan penempatan undangan). Setelah meteng selesai, Kepala Desa atau Tetua Desa mensosialisasikan rencana hajatan tersebut kepada masyarakat sekitar, dan mengupayakan kesepakatan bersama untuk melakukan gotong-royong; bahu-membahu mensukseskan pesta perkawinan.

Gotong-royong masyarakat desa tak sekedar menyumbangkan tenaga. Dalam perkawinan dan paggelan, tradisi ini terwujudkan pula dalam antar mpatan, yang berarti menyumbangkan bantuan material guna memenuhi kebutuhan pokok pesta perkawinan atau panggelan. Dalam antar mpatan, masyarakat menyumbangkan beras, ayam, itik, pulut (ketan), gula dan sebagainya. Tradisi ini dianggap menyimpan nilai kebudayaan dengan maksud meringankan beban penyelenggara hajatan, dan nilai keagamaan dengan harapan mendapatkan balasan di akhirat kelak.

Perkawinan atau panggelan (selamatan) di Sungai Kelambu mampu membumikan harmonisasi dan penghargaan antarsuku. Ketika pesta digelar di sebuah dusun, seluruh suku di sana menjadi tetamu. Pesta perkawinan memberikan bilik atau ruang khusus dan makanan khusus bagi tetamu yang beragama lain. Seumpama suku Dayak atau Cina menyelenggarakan pesta perkawinan, suku Melayu-Muslim yang diundang akan menempati ruang khusus dengan hidangan khusus. Untuk tetamu suku Melayu-Muslim, suku Dayak atau Cina sengaja meminta seorang Muslim untuk menyembelih dan memasak binatang sembelihan yang halal dimakan menurut ajaran Islam. Suku-etnis tersebut juga bakal menyediakan peralatan masak khusus, guna meyakinkan kualitas kehalalan jamuan mereka bagi tetamu Muslim.

Tetamu Melayu-Muslim tidak hanya diundang dan dijamu secara khusus pada pesta perkawinan atau panggelan bagi suku Dayak atau Cina, melainkan pula biasa diminta untuk membacakan doa selamat, zikir dan selawatan. Sang pemimpim pembacaan doa selamat, zikir dan selawatan. Hari raya keagamaan, seperti Natal, Imlek, Idul fitri dan Idul Adha, merupakan momentum klasik bagi seluruh suku di Desa Sungai Kelambu untuk melakukan silaturahmi. 
Suku Melayu akan mengunjungi suku Cina yang merayakan Raye Cine (Imlek), atau mengunjungi suku Dayak yang merayakan Natal. Demikian pula sebaliknya, Dalam suasana Raye Cine umpamanya, suku Cina akan menyuguhkan makanan khusus bagi tetamu Melayu-nya, misalnya saja kue lapis yang sengaja mereka pesan untuk dibuat oleh suku Melayu-Muslim, Maklumlah, suku itu paham bahwa si Muslim akan menaati ajaran Islam mengenai makanan, entah menyangkut kehalalan maupun ke-najis-an suatu hidangan. Di Sungai Kelambu, suku-etnis yang kebetulan memeluk agama non-Islam seolah-olah tak ingin "mengusik" keberagamaan tetamunya di hari raya keagamaan yang sedang mereka rayakan.

Ketika hari raya keagamaan datang, Idul Fitri, Idul Adha, Natal maupun Imlek, itu berarti undangan resmi bagi seluruh suku untuk mengunjungi rumah-rumah orang yang merayakannya. Di Sungai Kelambu, hari raya suatu agama (yang dipeluk oleh suku tertentu) seakan-akan merupakan hari raya semua agama (atau semua etnik). ${ }^{20}$

Di Desa Sungai Kelambu, "di sitok jak sian ade RT Mendure, Melayu, Dayak" (Di sini tidak ada RT Madura, RT Melayu atau RT Dayak). ${ }^{21}$ Suku bukanlah kelompok strukturalis-politis, meskipun setiap suku memiliki ciriciri khas dan identitas tertentu. Di Sungai Kelambu, jika sebuah rumah terpampang atau terpasang gambar Salib, itu petanda si pemilik rumah bersuku Dayak-Kristen. Jika sebuah rumah terdapat setanggi (dupa), itu petanda si pemilik rumah adalah orang Cina. Jika rumah tanpa ada tanda khusus, itu lumrahnya menunjukan rumah orang Melayu-Muslim. Penanda yang kadang terlihat di rumah orang Melayu adalah tempelan dinding bertuliskan kalimat berbahasa Arab, atau bahasa Indonesia; "Assalamu'alaikum," atau bahasa Inggris; "The Moslem Big Family," dan sejenisnya.

Menurut pengalaman Long Anwar, orang Dayak sangat toleran terhadap orang Muslim. Rumah-rumah orang Dayak umumnya menyimpan tikar pandan (tikar terbuat dari daun pandan), yaitu tikar yang hampir identik dengan kehidupan suku Melayu-Muslim. Jika rumah mereka berukuran cukup besar, maka bilik khusus disiapkan untuk menempatkan kedatangan atau peristirahatan tetamu Melayu-Muslim. Jika kebetulan sang tamu hendak

${ }^{20}$ Adalah kejadian biasa jika suku Melayu-Muslim mengambil peran dalam arakan Barongsai.

${ }^{21}$ Anwar, wawancara tanggal4 April 2010. 
menunaikan shalat di dalam rumah, maka pemilik rumah akan menunjukan arah kiblat. Ketika sang tamu memulai takbïrat al-ihrām, ${ }^{22}$ tuan rumah segera mengheningkan suasana rumah, sembari memperhatikan gerakan shalat hingga selesai.

Beragam suku yang tersebar di Dusun Parit dan Dusun Sungai tidak mengkonsentrasikan rumah-rumah mereka pada satu titik. Pola pemukiman suku yang menyebar memudahkan pembaruan antarsuku, sekaligus bisa menghalang-halangi faktor pengentalan ekslusivisme suku. Sungai Kelambu beruntung, karena sebuah keluarga Madura akan lebih mudah terpancing untuk mendekati dan mengintimi tetangga sebelahnya yang Melayu atau Dayak, ketimbang rekan Madura-nya di dusun yang sama. Kuantitas jarak fisik (tetangga) sebanding dengan kualitas jarak sosial (harmoni).

Di Desa Sungai Kelambu, kehidupan antarsuku tidak hanya tampil dalam bentuk mendirikan rumah yang berdampingan atau bertetangga dengan suku lain, melainkan pula dalam bentuk kekeluargaan. Beberapa keluarga di Desa Kelambu merupakan keluarga dengan pola perkawinan campur.

\section{E. Struktur dan Institusi Pedesaan}

Sejalan dengan modernisasi struktur pemerintahan desa, wilayah Desa Sungai Kelambu yang luas ini dibagi menjadi dua dusun; Dusun Sungai dan Dusun Parit. Jika sebuah dusun dibentuk oleh sejumlah Rukun Warga (RW), maka sebuah RW dibentuk oleh sejumlah Rukun Tetangga (RT) sebagai unit struktural terkecil dalam pemerintahan desa. Desa Sungai Kelambu memiliki 7 (tujuh) RW dan 15 (lima belas) RT.

Dalam hal penyelenggaraan pemerintahan desa, Sungai Kelambu saat ini telah berupaya untuk memaksimalisasi dan memodernisasi peranan pemerintahan. Jika dibandingkan dengan sebagian besar desa lain di Kecamatan Tebas, maka demi meningkatan pelayanan terhadap masyarakat, aparatur desa Sungai Kelambu menerapkan sistem perkantoran modem.

Kantor Desa Sungai Kelambu terus mencoba menyediakan layanan prima. Setiap hari selalu ada aparatur kantor desa yang bertugas melayani

\footnotetext{
22 Yaitu gerakan mengangkat kedua tangan hingga sejajar dengan telingga, dengan telapak tangan terbentang ke arah kiblat, dan disertai bacaan tertentu. Takbïrat al-ihräm adalah gerakan pertama memulai shalat.
} 
keperluan masyarakat. Aparatur yang diwajibkan "ngantor" itu adalah pejabat struktural desa, yaitu Sekretaris Desa (Sekdes), Kepala Dusun (Kadus), dan Kepala Urusan (Kaur). Pelayanan harian desa ini meliputi semua hal administratif, seperti pembuatan Kartu Tanda Penduduk (KTP), Kartu Keluarga (KK), Surat Keterangan Lahir, dan sebagainya.

Masyarakat yang bermaksud menyelesaikan urusan kewarganegaraan di kantor desa, mengenal seluruh aparatur desa, baik mereka mengenalnya sebagai pejabat maupun sebagai penduduk desa, Antara aparatur desa dengan masyarakat telah terjalin hubungan sosial dan tradisional, sekaligus hubungan struktural dan politik.

\section{F. Integrasi Sosial yang Terbangun di Desa Sungai Kelambu}

Sungai Kelambu merupakan salah satu daerah di Kabupaten Sambas yang terkena dampak langsung dari konflik antar kelompok etnik di Sambas pada tahun 1999-2000 yang lalu. Dampak tersebut lebih banyak bersifat psikologis, ketimbang kerusakan secara fisik, Oleh karena itu, isu SARA masih dianggap hal yang sangat sensitif untuk diangkat ke permukaan dalam wacana dialog di daerah tersebut. Memori tentang konflik antarsuku yang terjadi di Sambas beberapa waktu yang lalu memang meninggalkan luka yang mendalam di kalangan masyarakat.

Berbicara tentang integrasi sosial antarsuku di Desa Sungai Kelambu, memang memiliki keunikan tersendiri dibandingkan dengan desa-desa lain di Kabupaten Sambas. Karena sebagaimana kita ketahui bahwa, setelah terjadinya konflik sosial tahun 1999, terjadi pengusiran (eviction) terhadap suku Madura dari Kabupaten Sambas. Tapi penelitian ini menemukan bahwa, suku tersebut dapat hidup berdampingan dengan damai dan saling dapat bekerjasama dengan baik. Tidak ditemukan adanya segresi di dalam masyarakat yang berdasarkan perbedaan suku. Bahkan, kerjasama dilakukan oleh anggota masyarakat baik dalam kegiatan gotong royong, kegiatan keagamaan hingga kegiatan yang berkenaan dengan pelaksanaan adat istiadat.

Namun demikian, secara implisit masih ada kesan "ketakutan" masyarakat untuk mengakui keberadaan suku Madura di Sei Kelambu. Berbagai penjelasan mereka kemukakan, seperti Madura yang berada di Desa Sei. Kelambu bukan lagi mumi dari suku Madura, akan tetapi telah merupakan hasil perkawinan campuran antara Melayu dan Madura. Ketakutan ini lebih 
dikarenakan oleh kekhawatiran bahwa, persoalan tersebut belum dapat diterima sepenuhnya oleh sebagian besar masyarakat Sambas. Masyarakat dianggap masih mudah terprovokasi dengan isu-isu suku, oleh karenanya walaupun sebenamya masyarakat menginginkan hidup damai, akan tetapi kehati-hatian terus menerus menghantui mereka.

Kehati-hatian masyarakat terkait dengan persoalan kesukuan karena di keseluruhan tempat di Kabupaten Sambas, memang masih terlalu beresiko membicarakan persoalan kesukuan, terlebih lagi tentang keberadaan suku Madura. Terungkap pula bahwa kekhawatiran masyarakat tentang pemasangan bendera kuning. ${ }^{23}$

Dengan kata lain, rasa ketakutan atau sensitivitas yang timbul dalam masyarakat Sei. Kelambu lebih dikarenakan kekhawatiran terhadap kemungkinan masyarakat lain di luar masyarakat Sungai Kelambu yang belum siap dengan proses integrasi ini. Hingga kini tidak diketahui secara pasti siapa yang bertanggung terhadap pemasangan jargon-jargon tersebut. Oleh karenanya para tokoh masyarakat belum mengambil langkah-langkah yang tegas dalam mengatasi persoalan tersebut. Namun masyarakat menaruh kekhawatiran terhadap persoalan-persoalan tersebut, yang dinilai dapat memprovokasi masyarakat.

Point kekhawatiran tokoh masyarakat dan agama Sei Kelambu yang takut mencabut bendera kuning ini menandai bahwa, secara internal ada kekhawatiran yang mendalam terhadap pengaruh dari luar desa, dengan kata lain hegemoni kekuatan majoritas dari ekstemal desa. Secara implisit ini menandakan ada semacam ketidak berdayaan masyarakat setempat dalam menghadapi tekanan yang dilakukan dari luar, meskipun secara tidak langsung.

Fenomena kekhawatiran akan perpecahan juga ditandai dengan adanya keinginan tokoh masyarakat di Sungai Kelambu, agar organisasi-organisasi yang berbasis suku tidak dibentuk di Sungai Kelambu. Karena menurut

${ }^{23}$ Bendera kuning ini biasanya dipasang sebagai bentuk simbul persatuan masyarakat Melayu, dan kesiapan mereka untuk "berperang"Pada saat terjadi friksi seputar masalah Hasan Karman (Walikota Singkawang) di Pemangkat telah dipasang bendera kuning di berbagai sudut kota. Bendera tersebut menandakan kondisi siaga dari masyarakat Pemangkat dan sekitamya menghadapi "peperangan". Bendera kuning juga melambangkan persatuan masyarakat Melayu dalam menghadapi peperangan. (Wawancara, tangga128 Juli 2010) 
pandangan mereka, hal tersebut hanya akan menyebabkan masyarakat terbelah ke dalam salah seorang tokoh di daerah tersebut. ${ }^{24}$

\section{G. Faktor-faktor yang Dapat Menggangu Integrasi Sosial di Sungai Kelambu}

Berdasarkan penelitian yang dilakukan ditemukan beberapa faktor yang dapat menganggu atau menciptakan distabilitas di Desa Sungai Kelambu.

\section{Masih Sensitifnya Isu tentang Madura di Seluruh Wilayah Sambas}

Secara umum harus diakui, secara keseluruhan wilayah Kabupaten Sambas masih masuk kategori "sensitif" dengan persoalan-persoalan kesukuan. Terlebih lagi jika berurusan dengan suku Madura. Hal yang sama berlaku di Desa Sungai Kelambu, sebenamya di kalangan masyarakat itu sendiri relatif tidak ada masalah dengan suku Madura. Bahkan sebagaimana di kemukakan sebelumnya bahwa, komunitas Madura relatif aman di Sungai Kelambu. Namun, karena di daerah-daerah lainnya (termasuk di daerahdaerah sekitar Sungai Kelambu seperti Pemangkat dan Tebas) masih belum dapat menerima keberadaan orang Madura kembali di Sambas, daerah Sungai Kelambu turut terimbas dengan persoalan tersebut. 25

Tampaknya memang ada pihak-pihak yang "memelihara" rasa permusuhan atau "ketakutan" dalam masyarakat. Salah satunya dengan memprovokasi lewat cara-cara seperti penyebaran bendera kuning, pamfletpamflet dsb. Namun harus diakui sulit mengidentifikasi pihak-pihak yang dimaksud secara jelas. Bukti lain bahwa, proses ini terjadi secara tidak alami (ada pihak-pihak yang berkepentingan) adalah masih ada ketakutan untuk

24 Tidak seperti di daerah lainnya, Sungai Kelambu sengaja untuk tidak dibentuk lembaga / majelis suku seperti HIMMA (Himpunan Masyarakat Madura), MABT (Majelis Adat Budaya Tionghoa) dan MABM (Majelis Adat Budaya Melayu) karena dikhawatirkan akan mempertajam dan mengkotak-kotakan suku-suku yang ada di Sungai Kelambu .

25 Sebagai contoh, pada saat penelitian ini dilakukan di beberapa tempat termasuk di Pemangkat, Tebas dan Sungai Kelambu banyak bermunculan bendera kuning. Bendera ini biasanya melambangkan solidaritas dan persatuan puak Melayu Sambas, salah satunya dalam menghadapi ancaman. Bagi sebagian kalangan juga bendera kuning melambangkan kesiapan masyarakat Melayu untuk "berperang". Pada saat itu, bendera ini muncul terkait dengan kontroversi tentang Makalah Hasan Karman (Walikota Singkawang) yang dinilai oleh sebagian kalangan sebagai memojokkan puak Melayu. Fenomena ini memperlihatkan sensitifitas masyarakat berkenaan dengan persoalan kesukuan. Terlebih lagi jika persoalan kesukuannya berhubungan dengan isu-isu kemaduraan, maka persoalan akan semakin bertambah krusial. 
memaparkan secara terbuka tentang keberadaan orang-orang Madura di Sambas yang hingga kini selamat dan hidup berdampingan dengan baik dengan masyarakat Melayu Sambas. Karena alasan untuk keselamatan orangorang Madura dimaksud, maka diminta untuk tidak membuka informasi tentang hal tersebut secara terlalu vulgar.

\section{Ancaman Gagal Panen yang Berlansung Terus Menerus Dikhawatirkan akan Mempersempit Mata Pencaharian Masyarakat}

Sebagaimana jamak terjadi bahwa, konflik terjadi atau timbul dikarenakan rentannya perpecahan di dalam. Salah satu faktor penyebab rentannya masyarakat akan konflik adalah terkait dengan human security (keamanan manusianya) yaitu mencakup aspek lingkungan yang aman (environmental security) maupun pemenuhan terhadap kebutuhan-kebutuhan pokok (food, energy and economy, security). ${ }^{26}$

Berdasarkan pengamatan di lapangan tampak bahwa salah satu faktor yang dapat mendorong disintegrasi dalam masyarakat adalah karena persoalan pemenuhan kebutuhan hidup masyarakat. Masyarakat Sungai Kelambu yang selama ini mengantungkan kebutuhan hidupnya pada sektor pertanian, terancam mengalami persoalan yang serius karena dalam beberapa tahun terakhir ini pertanian di Sungai Kelambu mengalami kegagalan panen.

Sebagaian besar masyarakat Sungai Kelambau menggantungkan kehidupannya pada sektor pertanian, yaitu padi dan jeruk. Sebagai sumber mata pencarian utama selain tanaman jeruk, tanaman padi tak lepas dari berbagai persoalan hama penyakit, yaitu serangan wereng. Tak banyak tindakan yang dapat dilakukan masyarakat petani di Desa Sungai Kelambu lantaran minimnya wawasan mereka tentang hama penyakit. Pemerintah melalui Dinas Pertanian dan Petugas Penyuluh Lapangan (PPL) melakukan penyemprotan pestisida secara gratis diberikan kepada masyarakat yang me-

${ }^{26}$ The United Nations Development Programme (UNDP) mendefenisikan human security sebagai; first, safety from such chronic threats such as hunger, disease, and repression. Second, protection from sudden and hurtful disruptions in the pattems of daily life ---whether in homes, in jobs or in communities. Djamaluddin Darwis, dkk, "Integrasi Sosial (Studi Kasus Masyarakat Desa Korek Sungai Ambawang Kabupaten Pontianak)," (tidak diterbitkan), dibiayai oleh NUFFIC-WMC Semarang, 2008.), h. 17-18. 
milik lahan endemik hama. Namun, persoalan tidak selesai karena penyemprotan hama penyakit hanya dilakukan dengan melokalisir daerah endemik dengan luas $150 \mathrm{~m} 2$. Padahal sebaran hama penyakit tidak hanya menumpuk pada satu lahan pertanian. Dengan demikian, penanganan melalui penyemprotan yang dilakukan Dinas Pertanian dirasakan masyarakat Desa Sungai Kelambu masih belum optimal.

Berbeda dengan padi, tanaman jeruk merupakan komoditas unggulan di seluruh kawasan Sambas, tanpa terkecuali Desa Sungai Kelambu. Hama yang menyerang tanaman Jeruk lebih dikenal dengan virus CCVD, masyarakat lebih menyakini bahwa penyakit tanaman jeruk ini dibawa oleh hama kutu loncat. Melalui Dinas Pertanian tindakan preventif yakni dengan mengamputasi bagian batang yang terinfeksi penyakit, pihak dinas beranggapan serangan hama ini masih dalam kategori lambat, diperkirakan penyebaran hama $2 \mathrm{~cm} / 1$ bulan pada satu batang tanaman jeruk. Namun ternyata perkembangan serangan hama penyakit tanaman jeruk ini jauh lebih cepat dari prakiraan. Serangan hama tersebut dalam 1 minggu mampu membuat satu tanaman jeruk kering dan mati.

Kegagalan panen ini telah mengakibatkan masyarakat kesulitan memenuhi kebutuhan pokoknya. Hal ini tentu saja akan berimbas pada terganggunya human security masyarakat Sungai Kelambu. Sebagai akibatnya adalah masyarakat harus berpikir mencari altematif mata pencaharian lain, termasuk ada yang memilih pekerjaan sebagai TKI di luar negeri, terutama dari kalangan pemuda pemudinya. Remaja-remaja yang telah putus sekolah dan tak melanjutkan pendidikan mereka lebih memiliki animo dan impian besar untuk sukses dengan bekerja ke Luar Negeri seperti Malaysia, Brunei sebagai TKW (Tenaga Kerja Wanita). Selain itu ada juga masyarakat yang bekerja sebagai pemecah batu dan membuat jalan, karena bertepatan ada program pembangunan jalan raya di daerah tersebut oleh pemerintah. Namun, mata pencaharian seperti ini hanya untuk sementara waktu. Setelah itu, masyarakat harus berpikir mencari mata pencaharian lainnya.

\section{Masyarakat Tertutup dalam Membicarakan tentang Keberadaan Suku Madura}

Sikap tertutup masyarakat membicarakan tentang keberadaan orang Madura di beberapa tempat di Sambas, yang semula karena pertimbangan 
keamanan orang Madura itu sendiri, sepertinya tidak selalu baik, karena dengan demikian upaya menciptakan perdamaian positif (positive peace) di Sambas akan sulit didekati. Karena sesungguhnya, hal tersebut merupakan hal yang sangat konstruktif sekaligus modal dasar untuk membangun kembali perdamaian di Sambas.

Citra negatif yang melekat pada Sambas sebagai anak bangsa yang "mengusir" saudara setanah aimya sebenamya dapat dikikis dengan faktafakta ini. Pertanyaannya, sampai kapan fakta-fakta konstruktif ini akan terus menerus di "kubur". Tapi faktanya memang masih terlalu riskan, kalau sekarang persoalan ini dibuka secara vulgar. Masyarakat setempat sendiri yang tidak menginginkan hal tersebut terjadi. Dari awal penelitian ini dilakukan, waming ini telah disampaikan kepada peneliti, agar berhati-hati untuk mengungkapkan fakta-fakta yang ada. Seperti yang secara eksplisit dikemukakan oleh salah seorang tokoh masyarakat desa Sungai Kelambu bahwa kekhawatiran mereka terhadap orang Madura adalah orang luar desa yang mendengar informasi tentang orang Madura yang ada di desa Kelambu.

Dengan demikian, masyarakat desa Kelambu tidak menginginkan informasi tentang eksistensi orang Madura di Sungai Kelambu disampaikan secara terbuka ke pada masyarakat di luar Sungai Kelambu, karena pertimbangan aspek keamanan bagi orang Madura dan masyarakat Sungai Kelambu secara keseluruhan. Hal ini sebenamya juga mengesankan bahwa, masyarakat sesungguhnya menginginkan kehidupan yang lebih aman, tidak menginginkan kembali konflik tersebut terjadi.

Berbagai upaya masyarakat untuk menutupi persoalan ini, termasuk upaya pengaburan identitas suku masyarakat setempat juga dilakukan. Karena mereka tidak ingin keberadaan orang Madura menjadi konsumsi masyarakat luas. Ketakutan masyarakat ini berkali-kali ditekankan kepada peneliti. Walaupun fakta ini nyata dalam masyarakat, tapi secara teoritis ini menggambarkan ada tingkat kerentanan (level of vumarable) dalam masyarakat Sungai Kelambu sendiri atas ancaman kekerasan dari luar.

\section{H. Kesimpulan}

Berdasarkan hasil penelitian dan analisa yang dilakukan dalam penelitian ini dapat disimpulkan sebagai berikut: 
Pertama, secara umum hubungan (integrasi) sosial antara masyarakat lintas suku di Sungai Kelambu berjalan dengan baik. Hal itu ditandai dengan tingginya intensitas interaksi sosial antar masyarakat, tidak terjadi jarak sosial dan upaya menjaga keamanan dan harmoni bersama. Interaksi dan keriasama antara masyarakat berjalan dengan baik, bahkan terjadi perkawinan campuran antara suku. Namun demikian, integrasi tersebut mulai terganggu oleh hal-hal yang dapat memecah belah masyarakat. Persoalanpersoalan ini timbul bukan karena melemahnya ikatan integrasi diri dalam masyarakat Sungai Kelambu itu sendiri, akan tetapi sebagai akibat dari pengaruh-pengaruh dari luar Sungai Kelambu. Namun, imbas dari persoalan tersebut sangat signifikan bagi kelangsungan integrasi masyarakat Sungai Kelambu, akibatnya status integrasi di Sungai Kelambu menjadi sangat rentan (Unverable level), karena masyarakat menjadi terganggu secara sosial dan psikologis.

Kedua, terkait dengan modal sosial yang mempercepat atau memperkuat integrasi sosial di Sungai Kelambu, penelitian ini menemukan beberapa faktor, yaitu sebagai berikut: persamaan historis masyarakat Desa Sungai Kelambu yang berdampak pada kebanggaan asal usul dan sebagai penanda identitas. Modal sosial integrasi sosial lainnya adalah kearifan lokal yang dipraktekkan oleh masyarakat Sungai Kelambu seperti tradisi Belale', tradisi panggilan (meteng, saprahan, antar mpatan, tolak bala' dan Tepung tawar), majelis dzikir dan ritual keagamaan lainnya. Kemudian, faktor ikatan kekerabatan antar warga masyarakat yang telah mengakui perkawinan campuran turut juga memperkuat integrasi sosial masyarakat Sungai Kelambu.

Faktor letak geografis Desa Sungai Kelambu yang strategis menjadi daerah penghubung antara berbagai desa di Kecamatan Tebas juga menjadi faktor positif bagi Desa Sungai Kelambu untuk menjadi daerah yang terbuka untuk terjadinya interkasi lintas masyarakat dan budaya. Faktor lainnya yang tidak kalah penting mendukung integrasi sosial adalah peran lembaga kemasyarakatan desa yang berfungsi secara efektif dalam menjaga harmoni dalam masyarakat. Modal budaya ini dari semula sudah tumbuh dalam masyarakat, tapi terjadi secara sporadis sebagai tradisi yang diwariskan secara turun temurun, Ketika terjadinya konflik sosial, maka terjadi upaya penguatan atau revitalisasi modal budaya tersebut menjadi modal sosial terjadinya integrasi sosial dalam masyarakat. 
Namun demikian, ada juga faktor yang menghambat integrasi sosial, diantaranya adalah proses penyebaran identitas masyarakat sebagai akibat dari "rasa kekhawatiran" masyarakat terhadap ancaman dari luar desa. Kemudian, sikap tertutup masyarakat dengan dalih menjaga keamanan, suatu waktu bisa menjadi bumerang bagi masyarakat, karena masyarakat akan "terpenjara" oleh rasa keterikatan pada diri mereka sendiri.[w] 


\section{BIBLIOGRAFI}

Agus Salim (ed.), Teori dan Paradigma Penelitian Sosial (Pemikiran Norman K Denzin dan Egon Cuba dan Penerapannya), Yogyakarta: Tiara Wacana, 2001.

Alpha Amir Rahman, (ed.) Revitalisasi Kearifan Lokal: Studi Resolusi Konflik di Kalimantan Barat, Maluku, dan Poso, ICIP, 2007.

Alo Liliweri, Prasangka dan Konflik: Komunikasi Lintas Budaya Masyarakat Multikultur, Y ogyakarta, LKiS, 2005.

Collins, James T., "Sukuitas dan Identitas di Kalimantan Barat: Tinjauan Ilmu Lingusitik," Makalah, disampaikan pada Seminar Koloqium Dayak Islam oleh STAIN Pontianak, 2000.

Djamaluddin Darwis, dkk, "Integrasi Sosial (Studi Kasus Masyarakat Desa Korek Sungai Ambawang Kabupaten Pontianak)," (tidak diterbitkan), dibiayai oleh NUFFIC - WMC Semarang, 2008.

Eka Hendry, Monopoli Tafsir Kebenaran: Wacana Keagamaan Kritis dan Kekerasan Kemanusiaan, Pontianak: Kalimantan Persada dan The Ford Foundation, 2003.

Eka Hendry, dkk., Prasangka Antar Kelompok Suku di Kalimantan Barat, Pontianak: STAIN Pontianak Press, 2003.

Eka Hendry, Sosiologi Konflik (Telaah Teoritis Seputar Konflik dan Perdamaian), Pontianak: STAIN Pontianak Press, 2009.

Ferdinand Tonnies and Charles P. Loomis, Gemeinschaft and Gesellschaft" dalam Reading in Sociology, Mc. Clung Lee (eds.), Bamers and College Outlines Series, 1960.

Gerungan, W.H., Psikologi Sosial, Bandung: Refrika Aditama, 2000.

Ibnu Khaldun, Muqaddimab Ibnu Khaldun, Beirut: Darul Fikr, t.th.

Koentjaraningrat, Masyarakat Desa di Indonesia Masa Ini, Jakarta: Yayasan Badan Penerbit FE UI, 1964.

Koentjaraningrat, Beberapa Pokok Antropologi Sosial, Jakarta: Dian Rakyat, 1967. 
Depdikbud, Kamus Besar Bahasa Indonesia, Jakarta: Balai Pustaka, 1998.

Kristianus, Kisah Penting dari Kampung, Pontianak: STAIN Press, 2009.

Latif Wiyata, Corak, Korflik Kekerasan dan Harga Diri Orang Madura, LKiS, Yogyakarta, 2002.

Lexy J. Moeleong, Penelitian Kualitatif, Bandung, Remaja Rosdakarya, 2001.

Myron Weiner (eds.), Modemization: The Dynamic of Grouth, Cambridge-Mass: Voice of America Forum Lectures, 1966.

Munawar, Sejarah Konflik Antarsuku di Kabupaten Sambas, Pontianak: Kalimantan Persada dan The Ford Foundation, 2003.

Marzali, "Perbedaan Suku dalam Korflik: Sebuah Analisis Sosio Ekonomi terhadap Kekerasan di Kalimantan", dalam Stokhof. W.A.L dan Djamal, mumi (ed.), Konflik Komunal di Indonesia Saat ini, Jakarta: Indonesia-Netherlands Cooperation en Islamic Studies (INIS), 2003.

Maurice Duverger, Sosiologi Politik, Jakarta: Raja Grafindo Persada, 1993.

Neil J. Smelser, Sociology and The Other Sosial Science; P.F, LazarsJeld The Uses of Sociology, New York: Basic Books Inc. 1967.

Nurma Ali Riduan, “Landasann Keilmuan Kearifan Lokal, “Jumal Ibda'Vol. 5 No.1, P3M STAIN Purwokerto, 2007.

Robert. K. Yin, Studi Kasus: Desain dan Metode, Jakarta: Raja Grafindo Persada, 2005.

Soerjono Soekanto, Sosiologi Suatu Pengantar, Jakarta: Raja Grafmdo Persada, , 1982.

Supriyanto, Antropologi Kontekstual, Jakarta: Pusat Perbukuan Departemen Pendidikan Nasional, 2009.

Winston Tellis; (1997), "Introduction to Case study," The Qualitative Report, VoL 3 No. 2, Oktober $10^{\text {th }} 2008$.

William F, Ogbum \& Meyer F. Nimkoff, Sociology, Boston: A Pfeffe and Simons Intemational University Edition, Toughton Miffilin Company, 1964.

\section{Internet:}

http://punggeti-sosial.blogspot.coml2008 0101 archive.html

http://wapedia.mobilid/integrasi sosial. 
bttpi//www.1 saf.org/ content/view /176/150 .revitalisasi kearifanlokal.

http:/blog.unila.ac.id/abdulsyani/files/2009/10/teori-integrasi dan disintegrasisosial-sdh.pdf 
